Pedagogy

Konoh, 2007 - Konoh A.P. Theoretical and methodical bases of professional training of future specialists in sports and health tourism in higher educational institutions: author's ref. dis ... Dr. ped. Sciences: 13.00 .04 Theory and methods of vocational education. Kyiv., 2007. $42 \mathrm{p}$.

Mishchenko, 2001 - Mishchenko T.M. Pedagogical bases of preparation of future teachers for local lore work in rural school: author's ref. dis ... cand. ped. Sciences: 13.00.04- theory and methods of professional education. Ternopil, 2001. 20 p.

Obozny, 2002 - Obozny V.V. Local lore education in the system of professional teacher training: author's ref. dis. ... Dr. Ped. Science. Kyiv, 2002. 40 p.

On organized tourist trips, recreation with a full range of services and comprehensive tours: Order of the Verkhovna Rada of Ukraine of March 11, 2015 № 200-r. URL: http://zakon5.rada.gov.ua/laws/show/200-2015$\% \mathrm{D} 1 \% 80$ (access date 11.05.2018).

Rozhi, 2016 - Rozhi I.G., Braslavska OV Application of GIS in planning educational tourist and local lore routes on the example of the city of Uman, Cherkasy region. Problems of continuing geographical education and cartography : Coll. Science. etc. Vip. 23. Kharkiv: KhNU named after VN Karazin, 2016. S. 34-40.

Serebriy, 2008 - Serebriy V.S. Tourist and local lore work: problems and prospects. Local lore. Geography. Tourism. 2008. № 24. S. 6-8.

Stepanchenko, 2017 - Stepanchenko N.I. System of professional training of future teachers of physical education in higher educational institutions: dis. ... Dr. ped. Sciences: 13.00.04 - theory and methods of prof. education. Vinnytsia, 2017. $629 \mathrm{p}$.

Sushchenko, 2013 - Sushchenko L.P. Current trends in the training of future professionals in physical education and sports. Bulletin of Chernihiv National Pedagogical University. Ser .: Pedagogical sciences. Physical education and sports, 2013.

Tkachivska, 2009 - Tkachivska I.M. Preparation of future teachers of physical culture for tourist and local lore work with students : dis. Cand. ped. Science. Ternopil, 2009. 217 p.

Тетяна Рибченко Кесер, аспірант Начіонального педагогічного університету імені М.П.Драгоманова
Tetiana Rybchenko Keser, PhD Student, National Pedagogical Dragomanov University

E-mail: kesert87@ukr.net

ORCID 0000-0002-4585-7134

\title{
ГЕНЕЗИС І СУТНІСТЬ ІНТЕРАКТИВНОГО НАВЧАННЯ ЯК ОСОБЛИВОЇ МОДЕЛІ ПЕДАГОГІЧНОЇ ВЗАЕМОДІЇ НА ПРИКЛАДІ ВИКЛАДАННЯ УКРАЇНСЬКОЇ МОВИ ТА ЛІТЕРАТУРИ У ВНЗ
}

\footnotetext{
У статті розглянуто теоретико-методологічні аспекти використання інтерактивного навчання та переваги інтерактивного навчання перед традиційними. Проаналізовано використання інтерактивного навчання, як в загальноосвітній так $і$ у вищій школі. Розкрито якості, якими повинен володіти майбутній учитель украӥнської мови та літератури.

Визначено перспективи застосування інтерактивного навчання у підготовці майбутніх учителів украӥнської мови та літератури. Розкрито зміст інтерактивних методів навчання та наведено найбільи уживані інтерактивні методи навчання у ВНЗ .

У статті доведено, ще інтерактивними мають бути не лише методи навчання, але й уся система підготовки майбутніх учителів украйнської мови та літератури. Адже застосування інтерактивного навчання у підготовці майбутніх учителів української мови та літератури треба розглядати не лише при взаємодії викладачів та студентів у ході аудиторної роботи, а й варто звернути увагу $і$ на взаємодію між викладачами фахових дисииплін з метою обміну дидактичними доробками та методикою їх упровадження; між студентами в ході їх групової проектної діяльності; між учасниками освітнього процесу.
} 
Ключові слова: інновачійні методи навчання, інтерактивне навчання, інтерактивні технологї, інтерактивні методи і прийоми навчання.

The article considers the theoretical and methodological aspects of the use of interactive learning and the advantages of interactive learning over traditional ones. The use of interactive learning in both secondary and higher education is analyzed. The qualities that a future teacher of Ukrainian language and literature should possess are revealed.

Perspective for the use of interactive learning in the training of future teachers of Ukrainian language and literature are identified. The content of interactive teaching methods is revealed and the most used interactive teaching methods in universities are given.

The article proves that not only teaching methods should be interactive, but also the whole system of training future teachers of Ukrainian language and literature. After all, the use of interactive learning in the training of future teachers of Ukrainian language and literature should be considered not only in the engagement of teachers and students in the classroom, but also pay attention to the interaction between teachers of professional disciplines to exchange teaching aids and methods of their implementation; between students in the course of their group project activities; between participants in the educational process.

Keywords: innovative methods of teaching, interactive studying, interactive techniques, interactive methods and ways of studying.

Постановка проблеми. Підготовка висококваліфікованих фахівців, здатних ефективно використати свої знання в професійній діяльності, є основним завданням сучасної вищої освіти. Реалізація його потребує такої організації освітнього процесу, щоб студент не лише оволодів теоретичним матеріалом, а й міг самостійно здобувати нові знання, здійснювати пошук, аналіз, узагальнення та прогнозувати можливості застосування здобутих знань для ефективного виконання професійних завдань. Дієвим механізмом реалізації цього, на нашу думку, $є$ впровадження інтерактивного навчання, оскільки це сприятиме постійній комунікації викладача i студентів, що в свою чергу, стимулює процес пізнання, формує власну думку i вміння іiі аргументувати, вчить сприймати альтернативну думку і бачити різні шляхи розв'язання проблемних ситуацій, розвиває вміння працювати в команді і творчо підходити до засвоєння навчального матеріалу.

Аналіз останніх досліджень і публікацій. Теоретико-методологічні аспекти використання інтерактивного навчання розглянуті в роботах таких дослідників як В.П. Беспалько, В.І. Свдокимова， Л.В. Пироженко, О.І. Пометун, Г.К. Селевко, Г.О. Сиротенко та інших учених.

Memoю cmammi, як складової нашого дослідження, $є$ аналіз використання інтерактивного навчання, як в загальноосвітній так і у вищій школі.

Виклад основного матеріалу. У сучасному суспільстві відбуваються стрімкі зміни, які стосуються різних сфер його життя. Традиційна модель освіти практично вичерпала себе й не відповідає вимогам часу. Назріла необхідність у зміні способів педагогічної діяльності. Українське суспільство на сучасному етапі розвитку має особливо гостру потребу в самостійних, творчих особистостях, що усвідомлюють свою національність та здатні утверджувати свої принципи та переконання перед учнями.

3 прийняттям нової парадигми освіти (гуманістичної, особистісноорієнтованої) та поширенням педагогічних досліджень, об'єктом яких $є$ оновлені форми навчання, педагогічних методів та технологій інноваційного характеру, 
Pedagogy

розвитком науки управління в цілому, значно актуалізується проблема впровадження інноваційних технологій у освітній процес сучасної школи.

На сучасному розвитку освіти є різноманітні освітні технології, які допомагають вчителю раціонально побудувати процес навчання і досягти вищих результатів педагогічної діяльності. Школа надала вчителю можливість вибору у використанні інтерактивних технологій, спрямованих на всебічний розвиток та становлення творчої особистості учнів. Але відомо, що особистість може виховатись лише особистістю. А формування творчої особистості школяра проходить через творчу особистість вчителя.

Зазначимо, що «інтерактив» походить 3 англійської мови від слова «interact», де «inter» - взаємний, «асt» - діяти, тобто воно означає взаємодіяти. Тому інтерактивне навчання можна визначити як взаємодію викладача та студента 3 метою розв'язання навчальних та практичних завдань. Оскільки, сутність інтерактивного навчання полягає у взаємодії, то важливими чинниками цієї взаємодії є:

- присутність учасників в одному часі i/aбо просторі, що створює можливість особистого контакту між ними;

- наявність спільної мети, очікуваного результату діяльності, який відповідає інтересам усіх і сприяє реалізації потреб кожного;

- планування, контроль, коригування і координація дій;

- розподіл єдиного процесу співпраці, спільної діяльності між учасниками;

- виникнення міжособистісних відносин.

Таким чином, 3'ясували, що інтерактивне навчання - це спеціальна форма організації навчальної діяльності, яка має конкретну, передбачену мету - створити комфортні умови навчання, за яких кожен учень відчуває свою успішність, інтелектуальну спроможність.

Суть інтерактивного навчання полягає в тому, щоб навчальний процес відбувався за умови постійної, активної взаємодії усіх учнів. Це співнавчання, взаємонавчання (колективне, групове навчання у співпраці), де і учень, і вчитель $\epsilon$ рівноправними, рівнозначними суб'єктами навчання, розуміють, що вони роблять, рефлектують $з$ приводу того, що вони знають, вміють і здійснюють. Інтерактивне навчання передбачає моделювання життєвих ситуацій, використання рольових ігор, спільне вирішення проблеми на основі аналізу обставин та відповідної ситуації. Воно ефективно сприяє формуванню навичок і вмінь, виробленню цінностей, створенню атмосфери співпраці, взаємодії, дає змогу вчителю стати лідером колективу.

Інтерактивна взаємодія виключає як домінування одного учасника навчального процесу над іншим, так i однієї думки над іншою. Під час інтерактивного навчання учні вчаться бути демократичними, спілкуватися з іншими людьми, критично мислити, приймати продумані рішення.

Інтерактивне навчання - це діалогічне навчання, у ході якого здійснюється взаємодія вчителя й учня.

Мета інтерактивного навчання - створити комфортні умови навчання, за яких учень відчуває успішність, свою інтерактивну досконалість, що робить продуктивним сам освітній процес. 
Переваги інтерактивного навчання перед традиційним:

- у роботі задіяні усі учні класу;

- $\quad$ учні навчаються працювати у команді;

- $\quad$ формується доброзичливе ставлення до опонента;

- $\quad$ кожна дитина має можливість пропонувати свою думку;

- $\quad$ створюється «ситуація успіху»;

- $\quad$ за короткий час опановується велика кількість матеріалу;

- $\quad$ формуються навички толерантного спілкування;

- $\quad$ вміння аргументувати свій погляд, знаходити альтернативне рішення проблеми.

Призначення інтерактивного навчання - передати знання і усвідомити цінність інших людей. Основними формами інтерактивної роботи є навчальна взаємодія учнів у парах і мікрогрупах. Оптимальний склад групи - 4-6 осіб. Риси інтерактивного навчання:

- $\quad$ двобічний характер;

-

- $\quad$ керівництво процесу вчителем;

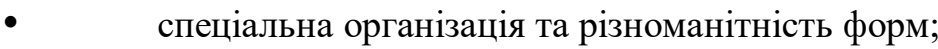

- $\quad$ інформаційна прогалина;

- $\quad$ цілісність та єдність;

- $\quad$ мотивація та зв'язок з реальним життям;

- $\quad$ виховання та розвиток особистості учнів одночасно 3 процесом засвоєння нових знань.

Наразі у ЗВО застосовують такі прийоми інтерактивного навчання [Зайченко, 2008].

- впровадження коротких діалогів зі студентами на лекції; проведення коротких підготовлених самостійно або під керівництвом викладача презентацій студентів у ході лекції, які б розкривали одне 3 питань, поставлених у ній; проведення коротких тестів на 5-10 хвилин, що демонстрували б розуміння студентами викладеного матеріалу, тощо;

- перетворення практичних занять у так звані «майстерні», тобто такі види занять, де студенти в ході обговорень, дискусій розв'язують завдання на основі власних самостійних напрацювань, а не просто «опитуються» за матеріалом лекцій;

- широке впровадження у практичні заняття презентацій, самостійно підготовлених студентами за завданнями викладача;

- впровадження рольових та ділових ігор;

- впровадження кейсів;

- включення до освітнього процесу як обов'язкової складової виконання студентами індивідуальних та групових короткострокових або довгострокових (протяжністю до одного семестру) навчальних проектів, які моделюють роботу за фахом;

- проведення майстер-класів на практичних заняттях; 


\section{Pedagogy}

- використання мультимедійних та електронних опорних конспектів лекцій, допоміжного навчального матеріалу на електронних носіях; процесу.

- Інтернет-пошук та Інтернет-комунікація між учасниками освітнього

Однак, таке навчання використовується фрагментарно у підготовці майбутніх учителів української мови та літератури, а ми вважаємо, що ефективність процесу навчання зростатиме, коли вдається організувати процес постійної багатосторонньої комунікації між учасниками освітнього процесу, де викладач i студент $\epsilon$ рівноправними учасниками процесу. Слід значно ширше розглянути перспективи застосування інтерактивного навчання у підготовці майбутніх учителів української мови та літератури і не лише при взаємодії викладачів та студентів у ході аудиторної роботи. Варто звернути увагу і на взаємодію між викладачами фахових дисциплін 3 метою обміну дидактичними доробками та методикою їх упровадження; між студентами в ході їх групової проектної діяльності; між учасниками освітнього процесу.

3 огляду на це, інтерактивними мають бути не лише методи навчання, але й уся система підготовки майбутніх учителів української мови та літератури.

Ключовим поняттям інтерактивного навчання $є$ взаємодія. О.І. Пометун та Л.В. Пироженко розглядають інтерактивне навчання, як певну форму організації навчально-пізнавальної діяльності, яка має створити комфортні умови навчання, за яких кожна особистість відчуває свою успішність та інтелектуальну спроможність [Пометун, 2004: с. 7].

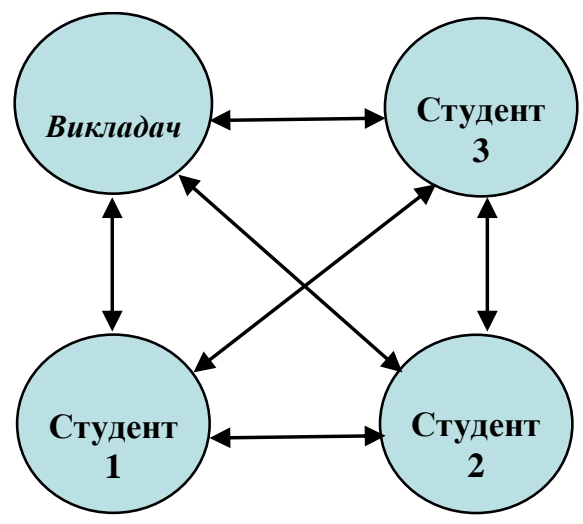

Рис.1.1. Модель багатосторонньої комунікації студентів та викладача

Суть впровадження методів інтерактивного навчання при вивченні фахових дисциплін базуються на постійній активній взаємодії викладача зі студентами, студентів між собою та з іншими суб'єктами освітнього процесу. У даному контексті викладач і студент є рівноправними учасниками освітнього процесу, викладач лише виступає як організатор процесу навчання, а важлими є зв'язки між студентами (рис. $1.1)$. 
3 досвіду викладання фахових дисциплін у закладі вищої освіти, робимо висновок про те, що ефективність використання методів інтерактивного навчання насамперед залежить від позитивної психологічної атмосфери в аудиторії, мотивації студентів для отримання технологічних знань i розуміння їх застосування в професійній діяльності і, звичайно, від матеріальної забезпеченості аудиторії необхідним обладнанням.

Незважаючи на спроби науковців класифікувати методи інтерактивного навчання, нині не існує загальноприйнятої класифікації. Колектив авторів, під редакцією О.І. Пометун, досліджуючи особливості класифікації методів інтерактивного навчання, визначає їх умовну робочу класифікацію за формами навчання (моделями), у яких реалізуються інтерактивні методи, а саме: технології кооперованого навчання, технології колективно-групового навчання, технології ситуативного моделювання, технології опрацювання дискусійних питань [Пометун, 2008: c. 32-57].

До методів інтерактивного навчання С.О. Сисоєва відносить: евристичну бесіду, презентації, дискусії, «мозкову атаку», «круглий стіл», «ділові ігри», конкурси практичних робіт з їхнім обговоренням, рольові ігри, навчальні тренінги, колективні вирішення творчих завдань, кейс-метод, практичні групові й індивідуальні вправи, моделювання певного виду діяльності або ситуацій, проектування й написання бізнес-планів, різних програм, обговорення відеозаписів, включаючи запис власних дій тощо [Сисоєва, 2011: c. 81-217].

А.М. Алєксєєва, досліджуючи інтерактивні комп'ютерні технології навчання, виділяє такі форми і методи інтерактивного навчання: робота в малих групах; метод каруселі, акваріум, броунівський рух тощо; лекція 3 проблемним викладом; евристична бесіда; семінар (у формі дискусій, дебатів); конференція; ділова гра; використання засобів мультимедія (комп'ютерні класи); технологія повноцінного співробітництва; технологія моделювання або метод проектів [Алєксєєва, 2012: C. $28-31]$.

Спираючись на педагогічний досвід та психологічні дослідження, зробимо висновок про те, що вибір методів інтерактивного навчання для підготовки майбутніх учителів української мови та літератури залежить від:

- професійних цілей освіти, виховання і розвитку особистості майбутніх учителів української мови та літератури;

- змісту і методики навчання конкретної фахової дисципліни;

- мети та завдань конкретного заняття;

- наявності часу, відведеного на вивчення даної теми;

- рівня навчально-матеріальної забезпеченості процесу навчання;

- розумових та індивідуальних можливостей майбутніх учителів української мови та літератури;

- педагогічної майстерності викладача.

Враховуючи вище сказане, у нашому дослідженні виділяємо такі методи інтерактивного навчання майбутніх учителів української мови та літератури у закладах вищої освіти:

- тренінги,

- навчальні дискусії; 
-

- інтерактивні лекції: проблемні лекції, лекція-візуалізація, бінарна лекція, лекція-прес-конференція;

- круглий стіл;

- кейси;

- $\quad$ мозковий штурм.

При викладанні фахових дисциплін, ми реалізовували такий інтерактивний метод підготовки майбутніх учителів української мови та літератури як тренінговий. Оскільки тренінг створює умови для саморозкриття студентів та зорієнтований на ефективне отримання нових знань, формування умінь і навичок, самостійний пошук способів вирішення професійних завдань, розширення набутого досвіду.

Ми підтримуємо думку К.Л. Мілютіної [Мілютіна, 2004], що тренінгова форма навчання має значні переваги, а саме: сприяє активності групи до отримання технологічних знань, поєднує процес опрацювання технологічних знань із емоційним ставлення до їх сприйняття, підвищує рівень мотивації до навчання фахових дисциплін, спонукає студентів до колективного мислення та прийняття рішень, практично перевіряє та закріплює отримані технологічні знання.

Підготовка до тренінгу включає декілька етапів: по-перше, визначення цілі та завдання тренінгу; по-друге, розроблення плану тренінгу; по-третє, налаштування студентів до проведення тренінгу (подати проблемні питання, які будуть обговорюватися); по-четверте, підготовлення аудиторії та матеріалів до проведення тренінгу (проектор, дошка, папір, маркери, роздаткові матеріали тощо).

Залежно від завдань програми навчання фахових дисциплін на тренінгових заняттях використовувалися такі методи: міні-лекція, дискусія, рольова гра, метод кейсів, мозковий штурм.

На нашу думку, використання дискусії в тренінговому занятті сприяло підготовці майбутніх учителів української мови та літератури шляхом доведення власної позиції та досягнення спільного рішення проблеми.

На початку навчальної дискусії обов'язково проводилися заохочувальні бесіди, де створювали позитивний емоційний настрій для проведення дискусії. Ефективність проведення навчальної дискусії залежить від іiі чіткої організація, а саме, визначення часу, необхідного для проведення дискусії, узгодженість з іншими видами роботи, планування дискусії, дотримання визначеного регламенту учасниками дискусії, підведення підсумків.

Спираючись на думку дослідників [Якимова, 2010; 32 c.], які розглядали особливості активізації навчальної діяльності у вищому закладі, вважаємо, що ефективність проведення дискусії у навчанні фахових дисциплін залежить від:

1. Вміння студентів доводити свою позицію аргументами та фактами.

2. Толерантності студентів до поглядів усіх учасників дискусії.

3. Стриманості у доведенні своєї думки стосовно питання дискусії.

4. Уміння визнати недостатність аргументації у викладенні своєї позиції.

5. Виявлення самокритичності та прагнення знайти істину.

Важливими моментами групової роботи $є$ опрацювання змісту і подання групами результатів колективної діяльності. Залежно від змісту та мети навчання можливі різні варіанти організації роботи груп. 
1. «Діалог». Суть його полягає в спільному пошуку групами узгодженого рішення. Це знаходить своє відображення у кінцевому тексті, переліку ознак, схемі тощо. Діалог виключає протистояння, критику позиції тієї чи тієї групи. Всю увагу зосереджено на сильних моментах у позиції інших.

Клас об'єднується у 5-6 робочих груп і групу експертів з сильних учнів. Робочі групи отримують 5-10 хвилин для виконання завдання. Група експертів складає свій варіант виконання завдання, стежить за роботою груп і контролює час. По завершенні роботи представники від кожної робочої групи на дошці або на аркушах паперу роблять підсумковий запис. Потім, по черзі, надається слово одному доповідачеві від кожної групи. Експерти фіксують спільні погляди, а на завершення пропонують узагальнену відповідь на завдання. Групи обговорюють і доповнюють iii. У зошити занотовується кінцевий варіант.

2. «Синтез думок». Дуже схожий за метою та початковою фазою на попередній варіант групової роботи. Але після об'єднання в групи і виконання завдання учні не роблять записів на дошці, а передають свій варіант іншим групам, які доповнюють його своїми думками, підкреслюють те, з чим не погоджуються. Опрацьовані таким чином аркуші передаються експертам, які знову ж таки зіставляють написане 3 власним варіантом, роблять загальний звіт, котрий обговорює весь клас.

3. «Спільний проект». Має таку ж мету та об'єднання в групи, що й діалог.

Але завдання, які отримують групи, різного змісту та висвітлюють проблему 3 різних боків. По завершенні роботи кожна група звітує і записує на дошці певні положення. У результаті з відповідей представників груп складається спільний проект, який рецензується та доповнюється групою експертів.

4. «Пошук інформації». Різновидом, прикладом роботи в малих групах $\epsilon$ командний пошук інформації (зазвичай тієї, що доповнює раніше прочитану вчителем лекцію або матеріал попереднього уроку, домашнє завдання), а потім відповіді на запитання. Використовується для того, щоб оживити сухий, іноді нецікавий матеріал.

Для груп розробляються запитання, відповіді на які можна знайти в різних джерелах інформації. До них можуть належати:

- роздатковий матеріал;

- документи;

- підручники;

- довідкові видання;

- доступна інформація на комп'ютері;

- артефакти (пам'ятки матеріальної культури);

- прилади.

Учні об'єднуються в групи. Кожна група отримує запитання по темі уроку. Визначається час на пошук та аналіз інформації. Наприкінці уроку заслуховуються повідомлення від кожної групи, які потім повторюються i, можливо, розширюються всім класом.

5. «Коло ідей» (Раунд Робін, кругова система). Метою «Кола ідей» $є$ вирішення гострих суперечливих питань, створення списку ідей та залучення всіх 


\section{Pedagogy}

учнів до обговорення поставленого питання. Технологія застосовується, коли всі групи мають виконувати одне і те саме завдання, яке складається з декількох питань (позицій), які групи представляють по черзі.

Коли малі групи завершують виконувати завдання і готові подати інформацію, кожна 3 них по черзі озвучує лише один аспект проблеми, що обговорювалась. Продовжуючи по колу, вчитель запитує всі групи по черзі, поки не вичерпаються ідеї. Це дасть можливість кожній групі розповісти про результати своєї роботи, уникаючи ситуації, коли перша група, що виступає, подає всю інформацію.

Як варіант можуть подаватись по колу результати не тільки групової, а й індивідуальної роботи. Цей метод є ефективним для вирішення проблемних питань. Для створення списку думок, точок зору можна попросити кожного учня по черзі запропонувати одну ідею усно або написати свою думку чи ідею на картці-індексі без імені. Вчитель збирає всі картки і складає список зазначених у них ідей на дошці або починає дискусію, користуючись інформацією з карток.

6. Акваріум. Ще один варіант інтерактивного навчання, що $є$ формою діяльності учнів у малих групах, ефективний для розвитку навичок спілкування в малій групі, вдосконалення вміння дискутувати та аргументувати свою думку. Може бути запропонований тільки за умови, що учні вже мають добрі навички групової роботи. Роботу організувати можна так: учитель об'єднує учнів у групи по 4-6 осіб і пропонує їм ознайомитися із завданням.

Одна $з$ груп сідає в центр класу (або на початку середнього ряду в класі, де стоять парти). Це необхідно для того, щоб відокремити діючу групу від слухачів певною відстанню.

Ця група отримує завдання для проведення групової дискусії, сформульоване приблизно так:

- прочитайте завдання вголос;

- обговоріть його в групі;

- за 3-5 хвилин дійдіть спільного рішення або підсумуйте дискусію. Доки діюча група займає місце в центрі, вчитель знайомить решту класу з завданням $\mathrm{i}$ нагадує правила дискусії у малих групах. Групі пропонується вголос протягом 3-5 хвилин обговорити можливі варіанти розв'язання проблемної ситуації. Учні, що знаходяться у зовнішньому колі, слухають, не втручаючись у хід обговорення.

Після цього місце в «Акваріумі» займає інша група й обговорює наступну ситуацію.

Висновки. Використання технологій інтерактивного навчання у професійній діяльності вчителя української мови літератури потребує не лише теоретичного ознайомлення із ними, а й перенесення цієї технології в освітнє середовище закладу вищої освіти, що призведе до значних змін в житті академічної групи, а також додаткових ресурсів для підготовки до такої форми взаємодії, як від студентів, так i від викладачів.

На основі одержаних результатів нашого дослідження можна переконатися, що використання інтерактивних технологій не тільки сприяє створенню в закладі освіти атмосфери співпраці, взаєморозуміння, а й реалізує основні засади особистісно-орієнтованого навчання.

Отже, з огляду на вищезазначене слід забезпечити підготовку майбутніх 
учителів української мови та літератури до впровадження інтерактивних технологій у викладання української мови та літератури, що неможливо реалізувати без впровадження цих технологій у вищих педагогічних закладах освіти.

\section{ЛІТЕРАТУРА}

Алєксєєва, 2012 - Алєксєєва А.М. Інтерактивні комп'ютерні технології навчання / А.М. Алєксєєва // Комп'ютер у школі та сім'ї. - 2012. - № 6. - С. 28 - 31.

Зайченко, 2008 - Зайченко І.В. Педагогіка : навчальний посібник для студентів вищих педагогічних навчальних закладів / І.В. Зайченко. - К.: «Освіта України», КНТ, 2008. - 528 с.

Мілютіна, 2004 - Мілютіна К.Л. Теорія та практика психологічного тренінгу: навч. посібник. / К.Л. Мілютіна. - К.: МАУП, 2004. - 192 с.

Пометун, 2004 - Пометун О.І. Інтерактивні технології навчання: Наук.-метод. посібн. / О.І. Пометун, Л.В. Пироженко. - К.: Видавництво А.С.К., 2004. - 192 с.

Пометун, 2008 - Інтерактивні технології: теорія та методика / Пометун О.І., Побірченко Н.С., Коберник Г.I. та ін.. - Умань-Київ. -2008. - 94 с.

Сисоєва, 2011 - Сисоєва С.О. Інтерактивні технології навчання дорослих: навч.- метод. посібн. / С.О. Сисоєва. - К.: ВД «ЕКМО», 2011. - 324 с.

Якимова, 2010 - Активізація навчального процесу у сучасній вищій школі: Метод. огляд / [уклад. Л.А. Якимова]. - К.: ДП «Вид. дім «Персонал», 2010. - 32 с.

\section{PEFERENCES}

Alieksieieva, 2012 - Alieksieieva A.M. Interaktyvni komp'iuterni tekhnolohii navchannia / A.M. Alieksieieva // Komp'iuter u shkoli ta sim'i. - 2012. - № 6. - S. $28-31$.

Zajchenko, 2008 - Zajchenko I.V. Pedahohika : navchal'nyj posibnyk dlia studentiv vyschykh pedahohichnykh navchal'nykh zakladiv / I.V. Zajchenko. - K.: «Osvita Ukrainy», KNT, 2008. - 528 c.

Miliutina, 2004 - Miliutina K.L. Teoriia ta praktyka psykholohichnoho treninhu: navch. posibnyk. / K.L. Miliutina. K.: MAUP, 2004. - $192 \mathrm{~s}$.

Pometun, 2004 - Pometun O.I. Interaktyvni tekhnolohii navchannia: Nauk.-metod. posibn. / O.I. Pometun, L.V. Pyrozhenko. - K.: Vydavnytstvo A.S.K., 2004. - 192 s.

Pometun, 2008 - Interaktyvni tekhnolohii: teoriia ta metodyka / Pometun O.I., Pobirchenko N.S., Kobernyk H.I. ta in.. - Uman'-Kyiv. - 2008. $-94 \mathrm{~s}$.

Sysoieva, 2011 - Sysoieva S.O. Interaktyvni tekhnolohii navchannia doroslykh: navch.- metod. posibn. / S.O. Sysoieva. - K.: VD «EKMO», 2011. - 324 s.

Yakymova, 2010 - Aktyvizatsiia navchal'noho protsesu u suchasnij vyschij shkoli: Metod. ohliad / [uklad. L.A. Yakymova]. - K.: DP «Vyd. dim «Personal», 2010. - 32 s. 


